\title{
Jeanette Little Scholarship Scheme Recipient Report
}

by Sarah Zaku

\section{JLSS PRESENTATION ANZTLA CONFERENCE 2015}
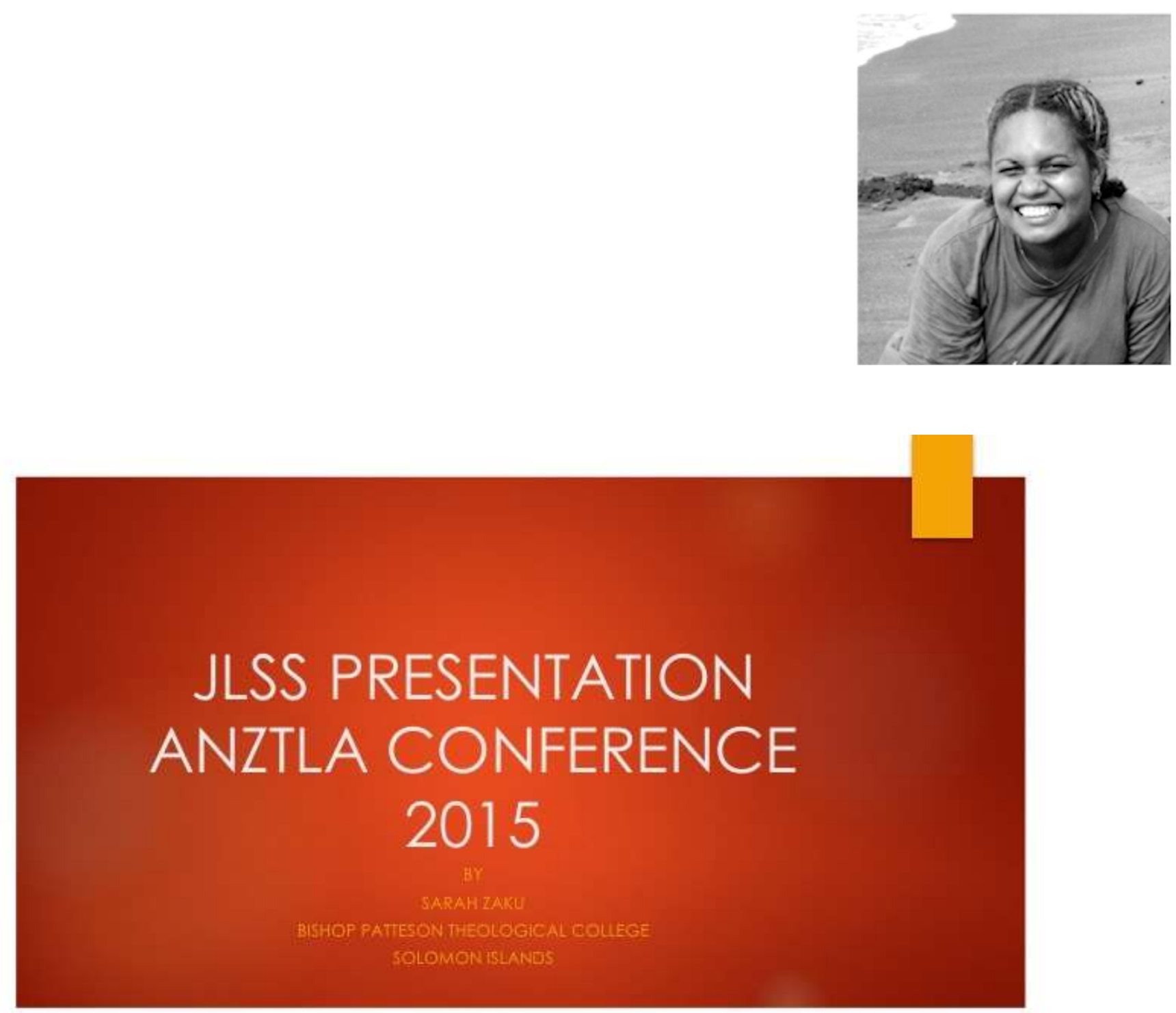


\section{BRIEF BACKGROUND ON MYSELF}
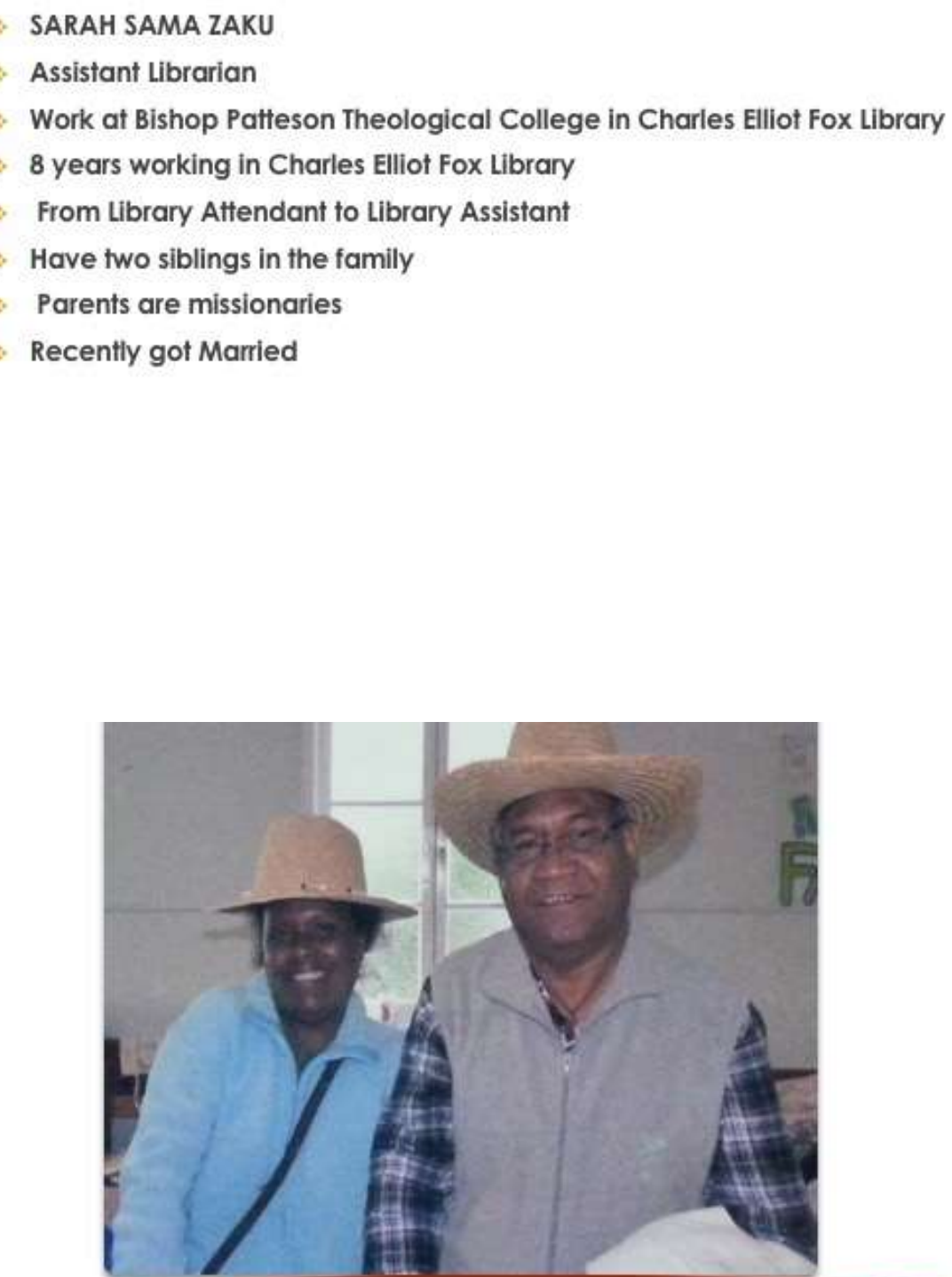

Above is the Picture of my Beautiful Parents Jenry and atkin 

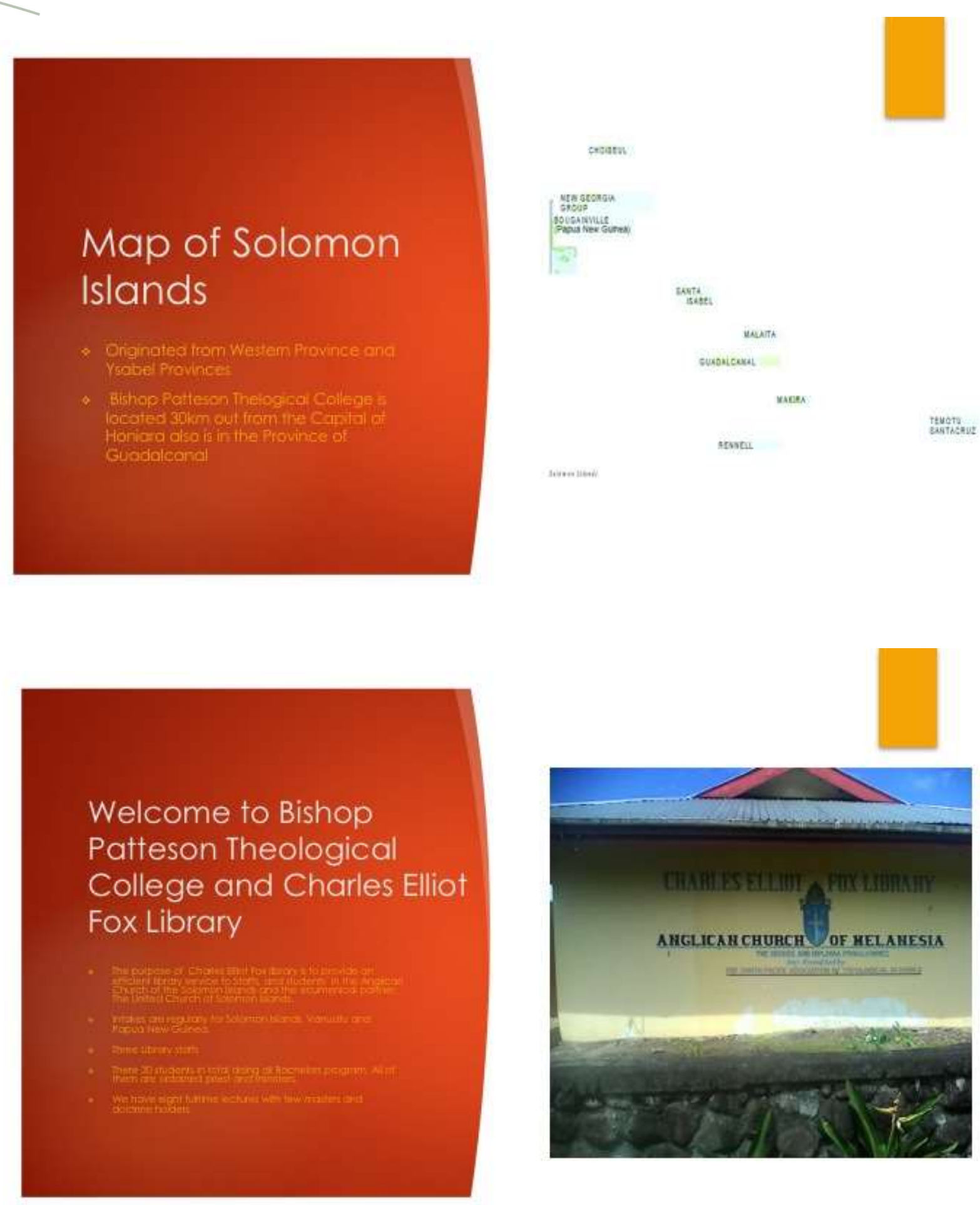


\section{Library from the inside}

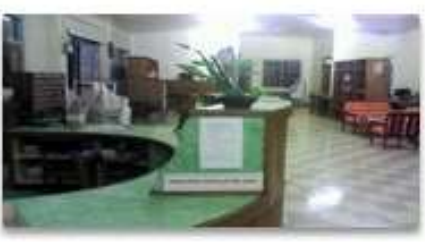

Circulation desk

Book loan to members fstaffs students, the BPTC Community

The library have no form of automated management systern

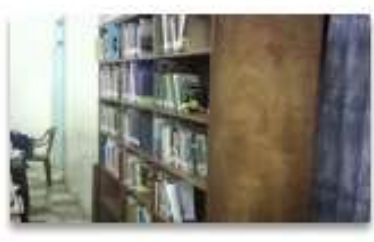

Pacific Collection shelf

Restricted materials only to be use in the library

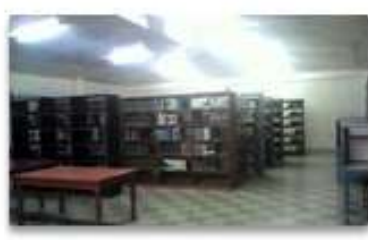

\section{Collections}

Present holding- 3899 (5ome are still in process:

- Donation/gitts are large in supporting the collections

\section{Few more Pictures in the library}

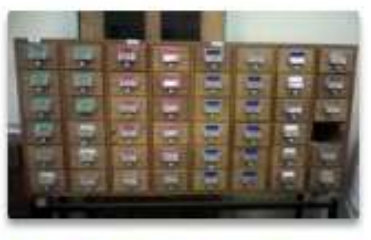

Manuel System (Uses catologue for Asthor. Title and Subject entries

Al resources are catalogue using

- DeweyDC

* Sears Subject Headings

Recently start importing data entries fram Irave and Library of Congress

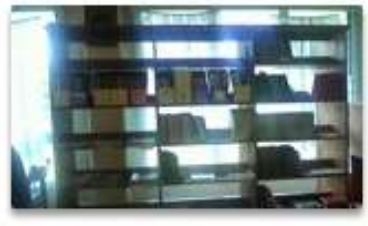

Periodicals and Journals

* Very much lack of Periodicals/Joumals

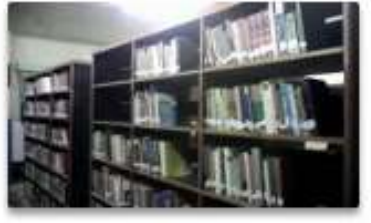

General Collection

* $3 / 4$ of our books are very old

* Most of the books are dated last $10-20$ years ago 


\section{My Role within the Organisation}

\footnotetext{
* Assistant Librarian

* Work within the Catalogue Division

* Delegated the responsibility for the functions of the unit.

* The Unit must have a work programme and produce monthly statistics for assessment.

* Answerable to the Librarian
}

\section{Why I am doing what I'm doing}

- Being in a theological college change ever aspect of my life

- Growing up with Parents who are missionaries I wanted to have the same experience they've come across when they are in mission but by working in a theological library I have come to experience their mission in another way

* Want to know more about God, people and the world 


\title{
Dreams, aims and aspiration
}

\author{
To be thankful with all that I \\ have \\ * To work as long as God wants me to in \\ Bishop Patteson Theological College. \\ * To be able to achieves some of the \\ goals that library desperately needs. \\ - Be able to complete my studies. \\ * To be the best in what I do and to share \\ my knowledge with others.

\section{Charles Elliot Fox Library} \\ * To have a have automated management \\ system \\ * To have fully air-condition in the library \\ building \\ 8 Rare/special collection to be store away in a \\ separate cool room. \\ - Have Access to $24 \mathrm{hr}$ power supply \\ 4 Trainings and workshops for the library staffs \\ \& Up to date with library collections (Books and \\ Periodicals
}

\section{LASTLY BUT NOT THE LEST}

I wish to express my thanks to the ANZTLA Board for accepting my application and to offer me this Jeanette Little Sponsorship Scheme.

Without your acceptance I will not make it this far to be able to learn more from you all who are here in this conference that have so much experience in library and scholars in this field.

I hope to take back what I will learn from this conference and implement it.

Thank you to you all

To God be the glory 